\title{
A thematic cartographic visualization of a small region, based on the example of the Mrozy Commune
}

\begin{abstract}
The purpose of this study was to produce a multifaceted presentation of a small region. It was realised based on two aims: the collection of spatial and statistical data, and the analysis of the data from the perspective of physical and socio-economic geography. Mrozy commune (Polish gmina Mrozy) is located in the eastern part of the Masovian voivodeship, in the county of Minsk (Polish - powiat miński).

The initial stage involved obtaining data from various sources. The second phase concerned the assessment of the data's quality. Next, appropriate visualization methods were selected; the authors used cartographic techniques for data presentation, resulting in a set of thematic maps at a scale of $1: 100,000$. The final part of this research concerned the evaluation of the results and the verification and correction of errors.

The accuracy of the maps for this small area has been checked and the maps will be made available to the local authorities.
\end{abstract}

Keywords

Thematic map $\bullet$ spatial data $\bullet$ statistical data $\bullet$ cartographic visualization $\bullet$ region - Mrozy commune

(C) University of Warsaw - Faculty of Geography and Regional Studies

\section{Introduction}

Nowadays there are many ways to visualize spatial data; the data can be presented in the form of text, tables, or maps. Each of these manners affects the user's viewpoint, and consequently, the difficulty in interpreting the data. The basic form of presentation is the table, which allows the reader to study particular data; however, cartographic visualization is more effective, allowing the reader to see connections between various phenomena.

This article addresses the visualization of spatial data for the commune of Mrozy. The motivation to take up this topic was due to the small amount of cartographic resources available for the Mrozy commune - no professional cartographic visualizations have been made of the Mrozy commune to date. The maps that have been developed so far are as follows: a general map, ${ }^{1}$ a map of protected areas (Juśkiewicz 2014), both of which are very generalized and without any scale; and a topographic map at a scale of $1: 45,000 .^{2}$

The aim of this article is to produce a multivariable thematic cartographic presentation of a small region. It is based on the collection and analysis of spatial and statistical data, and the preparation of a cartographic visualization of the research area from the point of view of physical and socio-economic geography.

\section{Research area}

Location

The Mrozy commune is located in the eastern part of the Masovian voivodeship (Polish - województwo mazowieckie). At 145 square kilometres, it is the largest commune in the county of Minsk. The population of the Mrozy commune is 8,500

\footnotetext{
${ }^{1}$ http://www.mrozy.pl/p,75,polozenie-i-mapa (25 August 2017)
}

${ }^{2}$ http://www.mrozy.pl/p,75,polozenie-i-mapa (25 August 2017)
Patrycja Fabijańska, Jolanta Korycka-Skorupa

Department of Geoinformatics,

Cartography and Remote Sensing, Faculty of Geography and Regional Studies, University of Warsaw, Poland e-mail:p.fabijanska@student.uw.edu.pl e-mail:j.skorupa@uw.edu.pl

Received: 19 November 2017

Accepted: 9 March 2018

inhabitants. The commune office is located in Mrozy, which has had town status since 1 January 2014 and is, therefore, one of the youngest towns in Poland. It is situated $58 \mathrm{~km}$ from Warsaw and $38 \mathrm{~km}$ from Siedlce (ed. Juśkiewicz 2014).

The Mrozy commune is located in the Central European Plain (Polish - Niż Środkowoeuropejski), in the macroregion of the Southern-Podlachia Plain (Polish - Nizina Południowopodlaska), which forms part of the Central Plains' sub-region (Polish - Niziny Środkowopolskie). The boundaries of the commune are located on the border of two mesoregions: the Kałuszyńska Upland (Polish - Wysoczyzna Kałuszyńska) and the Węgrów Plain (Polish - Obniżenie Węgrowskie) (Kondracki 2013).

The formation of the Mrozy commune is connected with the presence of the Pleistocene ice sheet in this area. There are many postglacial geomorphological forms: hills (the average height is about $5-10$ metres), eskers, and moraines. Aeolian accumulation forms (parabolic dunes) are located in the south and east of the commune. ${ }^{3}$

\section{Surface water}

The rivers that flow through the Mrozy commune area belong to the catchment area of the Vistula, Liwiec, and Bug rivers. In the southern part of this area, the watercourses are tributaries of the Świder river, which flows into the Vistula. The Witówka river, along with a network of drainage ditches, flows through the middle of the area. The Trytwa river flows through Mrozy town itself and divides it into northern and southern parts. A few years

${ }^{3} Z$ miana studium uwarunkowań $i$ kierunków zagospodarowania przestrzennego gminy Mrozy [Changes in the study of the conditions and directions of spatial development of Mrozy commune] 2012, p. 19 
ago a retention reservoir was built. Within the commune there are also many fish ponds that are often used for recreational purposes. (ed. Juśkiewicz 2014).

\section{Flora}

Forests cover $25 \%$ of the Mrozy commune's area. The majority of this area is covered with coniferous forests, with the typical species being the silver fir. Deciduous forests, especially alder forests, occur mainly in the river valleys. The lowlands are covered with meadows, whereas the dry habitats (dunes and hills) are covered with grasses. The wetlands are covered by reeds, especially by the common reed and the cat's-tail (ed. Juśkiewicz 2014).

\section{Fauna}

Most species of birds and mammals occur in the north and east of the Mrozy commune, which are forested areas - these include boar, deer, foxes, and woodpeckers. Skylarks and yellow wagtails are found in non-forested areas, meadows, and fields. Near farms, there are many mammals, such as martens and brown rats; as well as birds, such as white storks and sparrows (ed. Juśkiewicz 2014).

\section{Nature protection}

The Mrozy commune has many forms of nature protection :

- Protected Landscape Area - created to protect the environment; preserving the biological balance and areas that have been less transformed by man. The value of this area is in the occurrence of the common fir, meadow and water habitats, and the esker geological formations.

- Nature Reserves - five nature reserves have been created to protect plants and animals, geological forms, and wetlands occurring in the Mrozy commune.

- 'Bird' Natura 2000 Special Protection Area - includes the Kostrzyń river valley and tributaries, wetlands, and meadows; a region of agricultural landscapes that are home to many species of plants and animals. ${ }^{4}$

- 'Habitat' Natura 2000 Special area of conservation protecting one of the best wetland habitats on the SouthPodlachia Plain. ${ }^{5}$

- Natural monuments - there are more than 120 trees recognized as natural monuments in the Mrozy commune. These are not only single trees, but also entire avenues.

Research methodology

The starting point was to collect the data that were available from different sources. The data used in this research was acquired from the Mrozy commune office from vector data on land cover, and statistical data on population. The next source of data was the Centre for Geodesy and Cartography, from which the Database of Topographical Objects was obtained at a scale of 1:10,000 (BDOT10k). The Database of General Data, at a scale of 1:250,000 (BDOO), was also used. The final source of spatial data was the official website of the Directorate-General for Environmental Protection (GDOS) ${ }^{6}$ which provides free data on nature conservation for the community of Mrozy.

The second part of this article involves the assessment of the collected data. The data was checked in terms of completeness (it turned out that some of the data was lacking), topicality, details (the Mrozy commune is a small area), and usefulness for map design (the data deemed useful for visualization, was data with a spatial reference). A database was developed for the purposes of

\footnotetext{
${ }^{4}$ http://obszary.natura2000.org.pl (7 July 2017)

${ }^{5}$ http://obszary.natura2000.org.pl (7 July 2017)

${ }^{6}$ https://www.gdos.gov.pl (25 May 2017)
}

spatial data visualization. The data in this database was coded, generalized, and described. Furthermore, the database can be updated and expanded as needed.

The next stage was the selection of appropriate cartographic methods for visualization. In designing the map the authors used quantitative methods: the dot method (population distribution map), choropleth (population density map), and the proportional symbol map (population change map). Qualitative methods were also used: the symbol method, the range method (map of nature conservation), and the chorochromatic method (land cover map) (Ratajski 1989).

The next step in the visualization was the use of appropriate graphical variables for the phenomena presented by each map. Using the relevant graphical variables helps users to perceive the image, and helps express the variety of phenomena presented on the maps (Żyszkowska 2016). An important stage in the preparation of the maps was the creation of the legends so that the user could find information about the symbols on the map (Korycka-Skorupa 2002). The legend is 'the key to the map' that helps users to read and interpret the map correctly.

A map legend can also indicate how the map should be read and can assist in the reading of hidden information (Gołębiowska 2010). Properly constructed, legends help the phenomenon represented by thematic maps to be understood. The legends developed in this study are simple in form so they are easy to read and analyse (Gołębiowska 2015).

The final phase of the work was devoted to evaluating the results, correcting possible errors, and checking the effectiveness of the data presented for the small area of the Mrozy commune. It is important that the results are easy to interpret for all users. The results will be made available to local authorities. A simplified scheme of the research is shown in Figure 1.

\section{Results}

This section presents the results of the study. The series of thematic maps was developed at a scale of $1: 100,000$. The

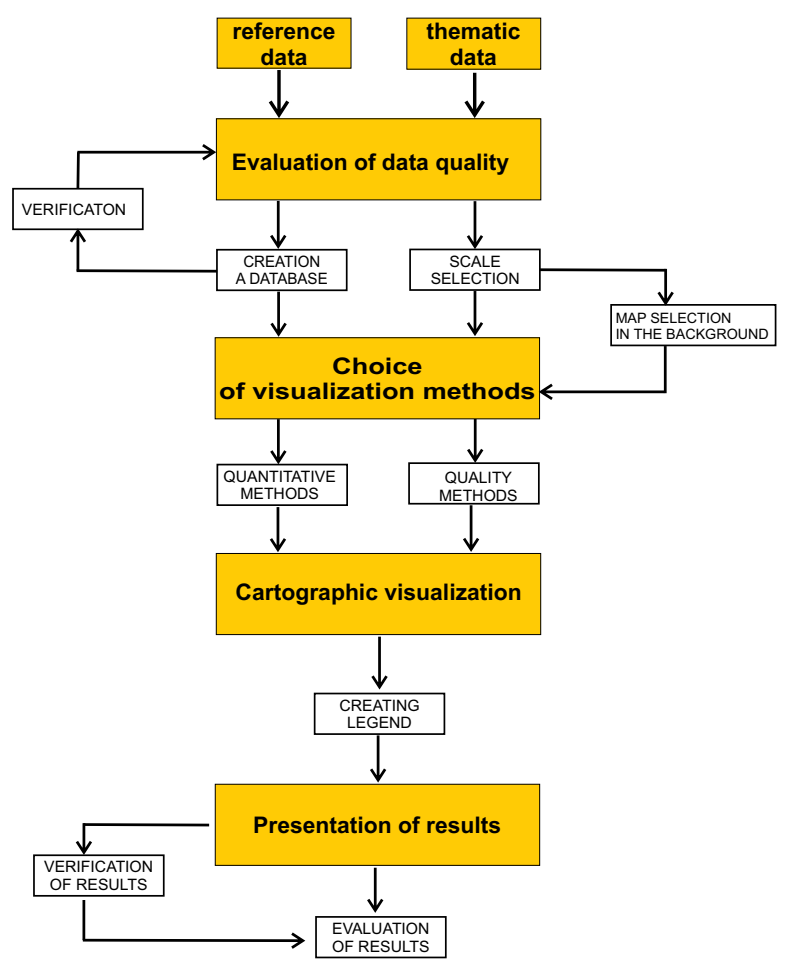

Figure 1. Study stages (own elaboration) 
coordinate system used for the maps was the Poland Coordinate System, 1992. ArcMap 10.3 software and the Corel Draw X6 graphic package were used for the cartographic presentation of the data.

\section{General map (Figure 2)}

The first map in the series is the general map, which presents the general situation of the Mrozy commune. The map was made using the chorochromatic method along with the symbols method. The base map is a contour map of the boundaries of the Mrozy commune. The primary objective was to create a background for the symbols, and for this purpose data from the land cover map was used. The roads were then divided into main roads, secondary roads, and local roads. The next step was to create the symbols that would mark the most important places in the Mrozy commune - places such as churches, pharmacies, monuments, health centres, and so on.

\section{Land cover map (Figure 3)}

The chorochromatic method was used to create the land cover map of the Mrozy commune. The data was acquired in cooperation with the commune office in Mrozy. The map contains nine forms of land cover: roads, railways, buildings, meadows, forests (deciduous, coniferous, and mixed), hydrography, and wetlands. The final step in creating this map was the selection of suitable colours for each form of land cover.

Map of nature conservation forms (Figure 4)

The Mrozy commune has many forms of nature protection:

- Protected landscape area

- $\quad$ Special areas of conservation ('Habitat' Natura 2000)

- $\quad$ Special protection areas ('Bird' Natura 2000)

- $\quad$ Five Nature Reserves

- Natural monuments

The map of protected areas was made using the range method, and is used to visualize protected areas: spot range (uniform colour without contour), pattern, and line coverage. Each one is different, so that users have no problem interpreting the map (Saliszczew 2002).

\section{Population map (Figure 5)}

This map was created by combining two methods of cartographic presentation.The first is choropleth method, 'probablu one of the most commonly used methods of cartographic presentation' (Slocum 2009).

Information about the population in the 26 rural administrations was obtained from the commune office in Mrozy. The map shows the relationship between population and area. The data has been divided into five population density classes, which makes it easier for the user to interpret it. The colours used (varying shades of yellow) are appropriate for this kind of data; as the intensity of the phenomenon increases, the colour becomes darker.

The second method is the proportional symbols method; this represents the numerical data associated with point locations (villages within the Mrozy commune). Each circle is individually proportional to the value it represents (Ratajski 1989).

Population distribution map (Figure 6)

The dot map shows the distribution of the population for the Mrozy commune. The base map is a contour map of the boundaries of the Mrozy commune. The most important parameters in determining the appearance of a dot map are dot size and unit value. The Mrozy commune has over 8,500 inhabitants, ${ }^{7}$ so the best option is a dot that symbolizes 10

${ }^{7}$ http://www.mrozy.pl/, (23 May 2017)

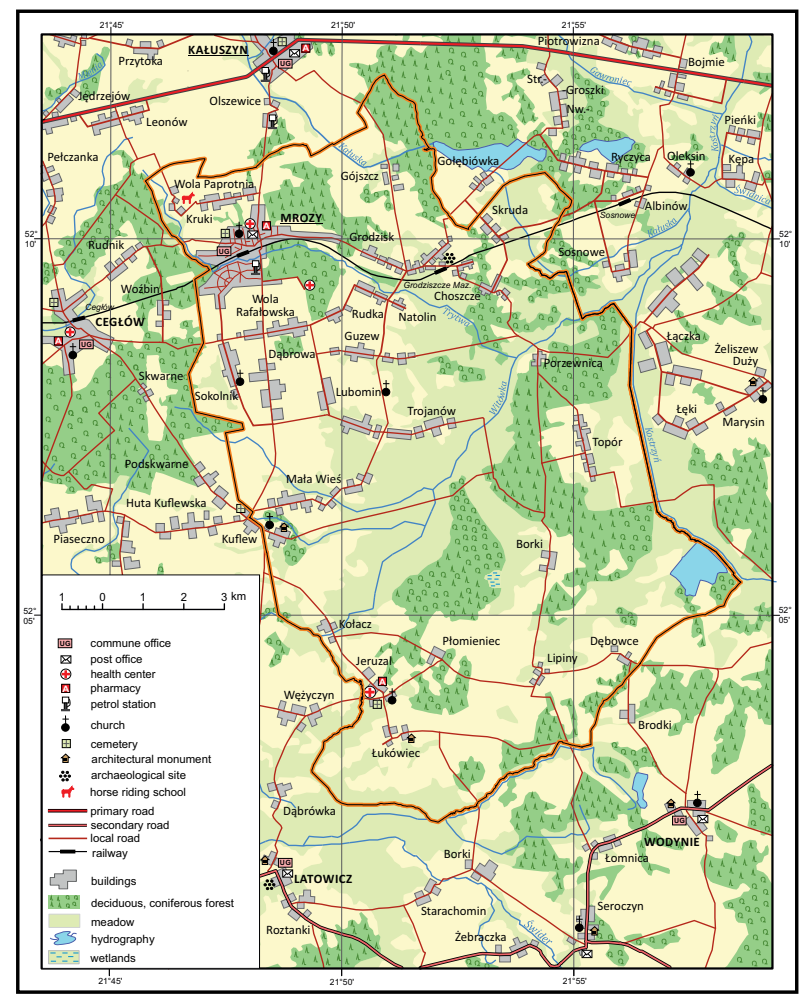

Figure 2. General map (reduced by 60\%) (own elaboration) The original size map is available in Supplementary Online Materials

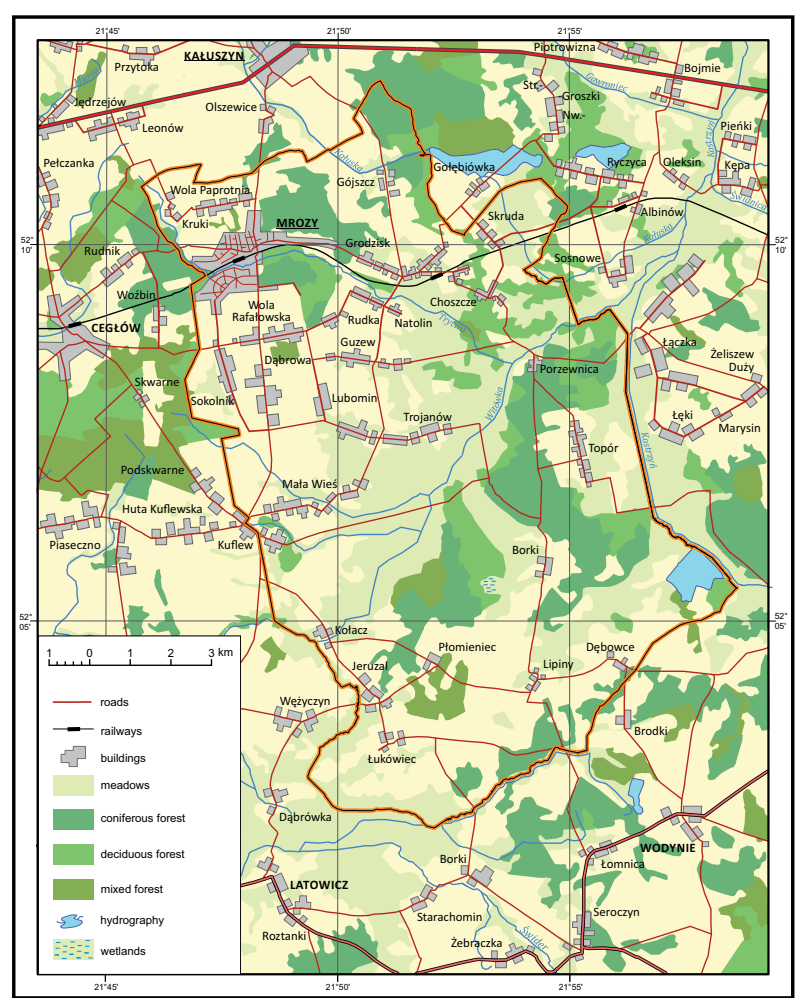

Figure 3. Land cover map (reduced by 60\%) (own elaboration) The original size map is available in Supplementary Online Materials 


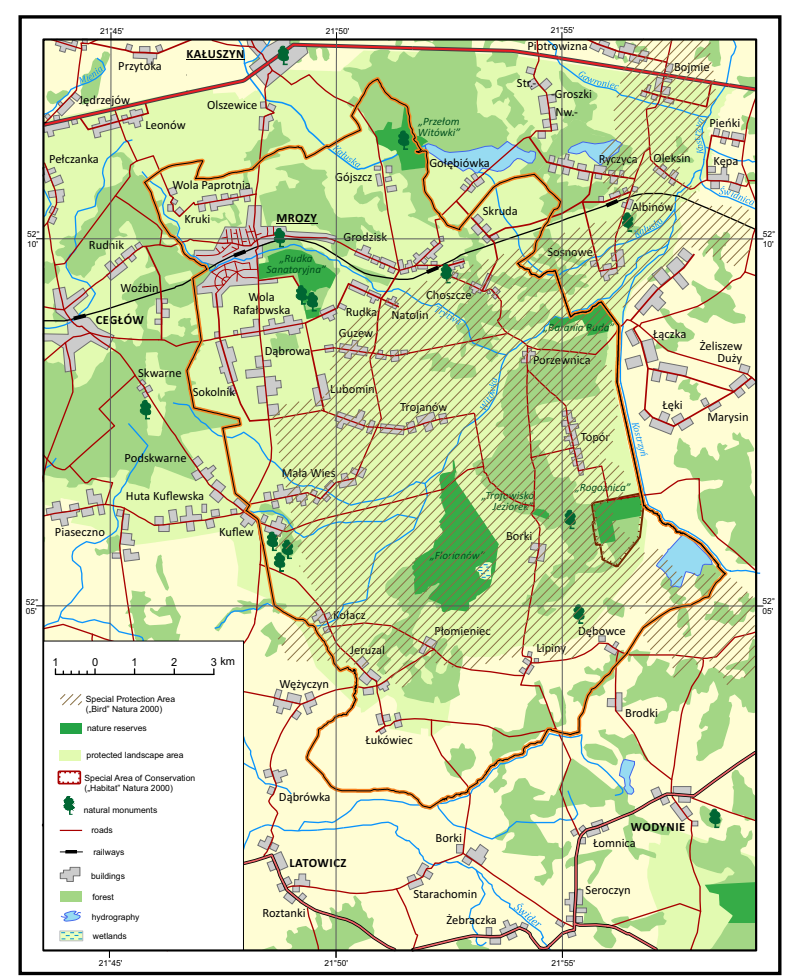

Figure 4. Map of protected areas (reduced by 60\%) (own elaboration) The original size map is available in Supplementary Online Materials

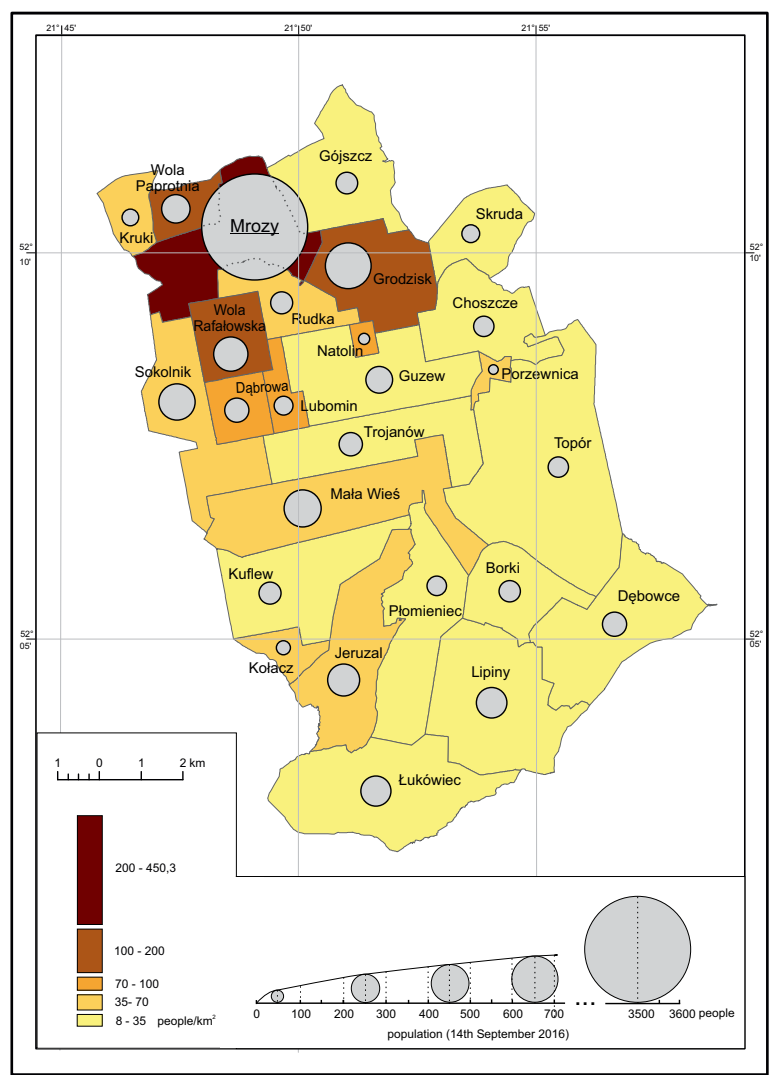

Figure 5. Population of the Mrozy commune (reduced by 60\%) (own elaboration) The original size map is available in Supplementary Online Materials

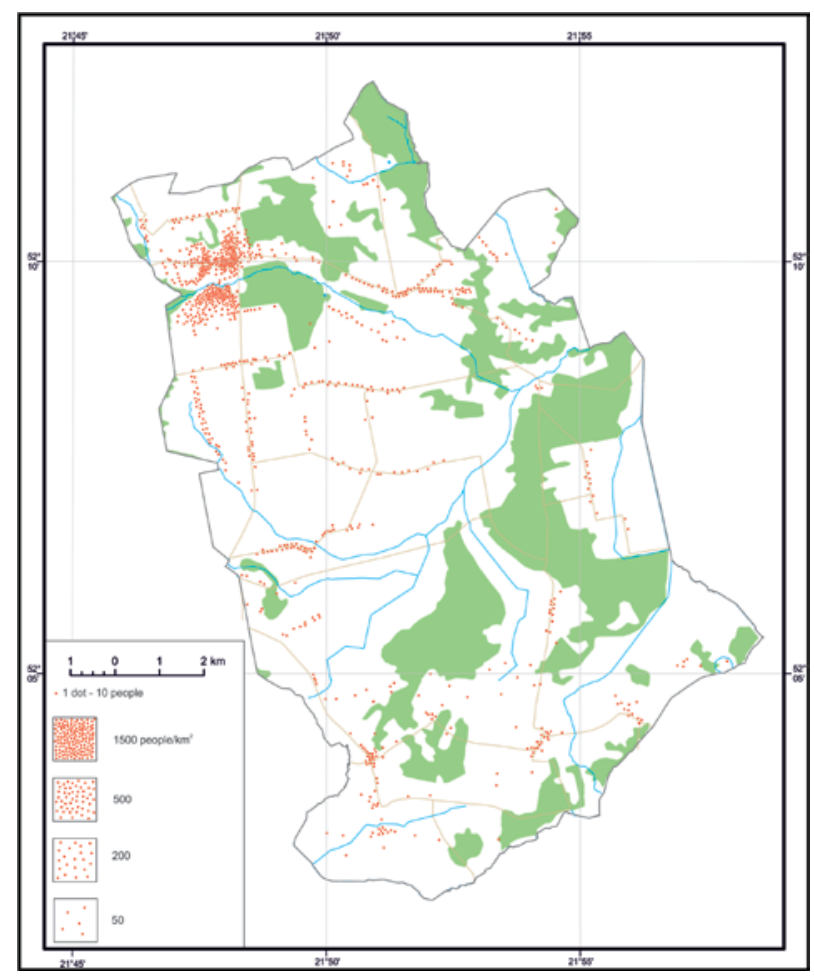

Figure 6. Population distribution for the Mrozy commune (reduced by $60 \%$ ) (own elaboration) The original size map is available in Supplementary Online Materials

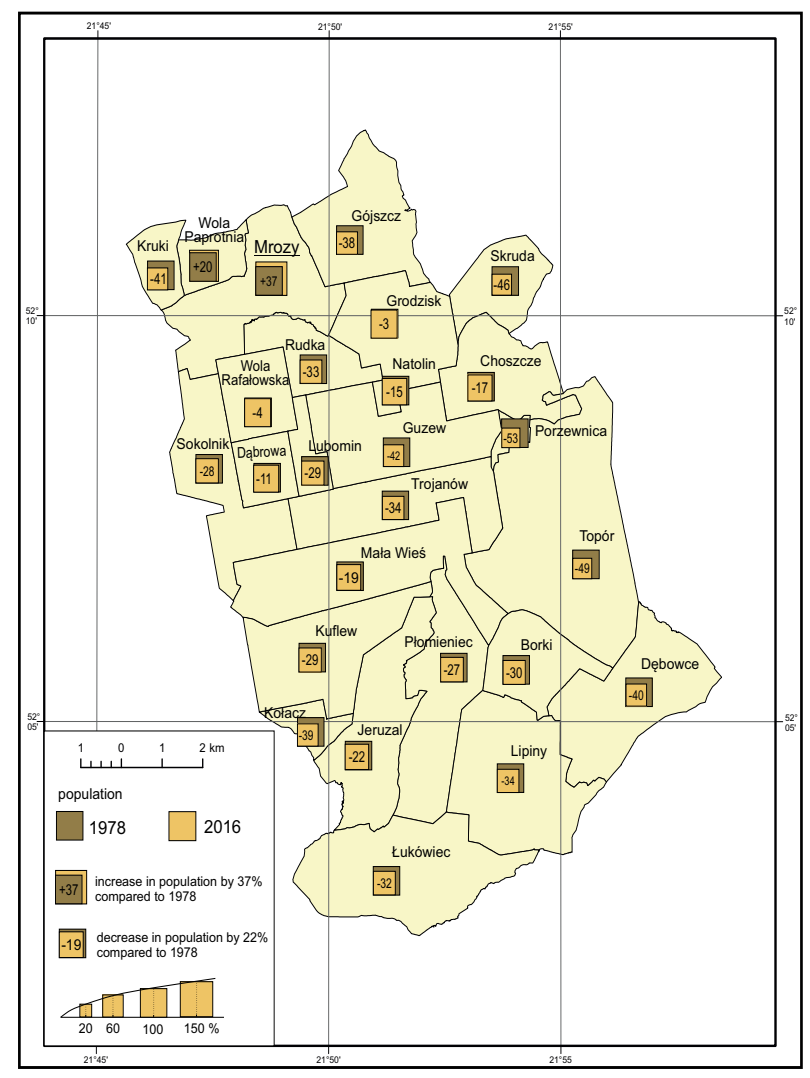

Figure 7. Map of population change (reduced by 60\%) (own elaboration) The original size map is available in Supplementary Online Materials 
inhabitants and has a diameter of $0.5 \mathrm{~mm}$ (Pasławski 2008). The applied topographic layout of dots means that they are located at the actual occurrence of the phenomenon (Spallek 2002). The dots are located manually, based on the geography of the commune's forests, rivers, and roads.

\section{Map of population change}

The purpose of this map is to show the population change during the period 1978-2016. The base map is a contour of the map of the boundaries of the Mrozy commune, from the BDOT10k. This time, the method used was a proportional symbol map - more specifically, squares.

The brown square has a fixed size $(100 \%)$; it represents the 1978 population and is the reference point for the orange square. The second square represents the 2016 population and its size is adjusted to the represented value (Ratajski 1989). It shows what percentage of the 1978 population makes up the 2016 population. The interpretation of the map is quite simple - a larger brown square means that the population has decreased, while a larger orange square means that the population has increased relative to 1978.

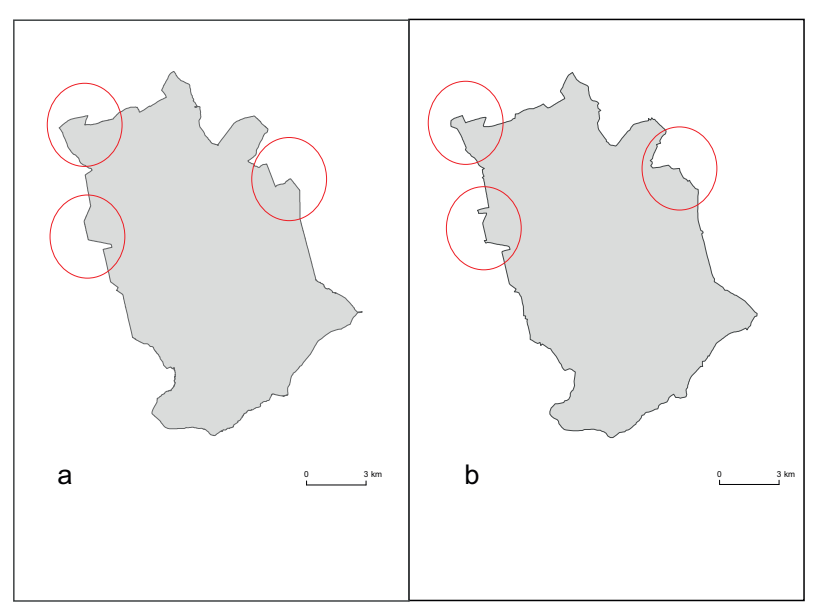

Figure 8. Differences in boundaries (scale reduced) (own elaboration)
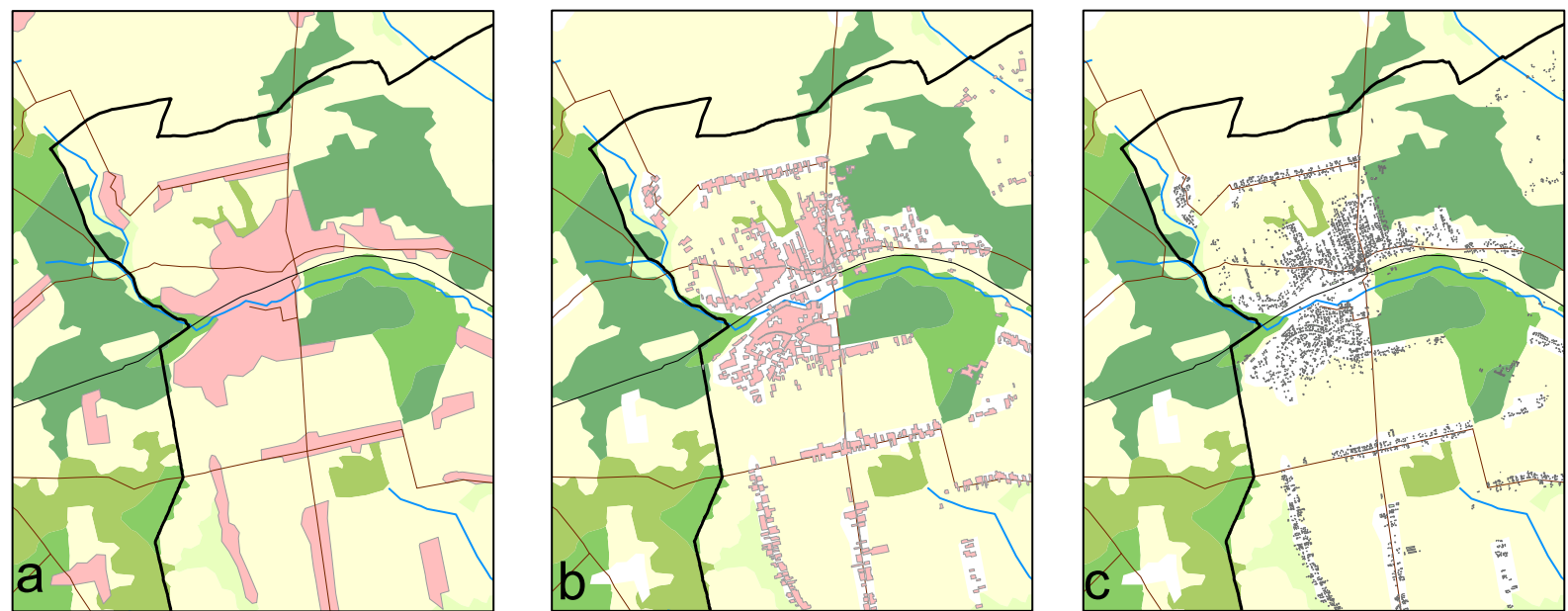

Figure 9. Three degrees of detail in the presentation of buildings: 'buildings' (9a.), 'built-up areas' (9b.), and 'individual buildings' (9c.) (own elaboration) 

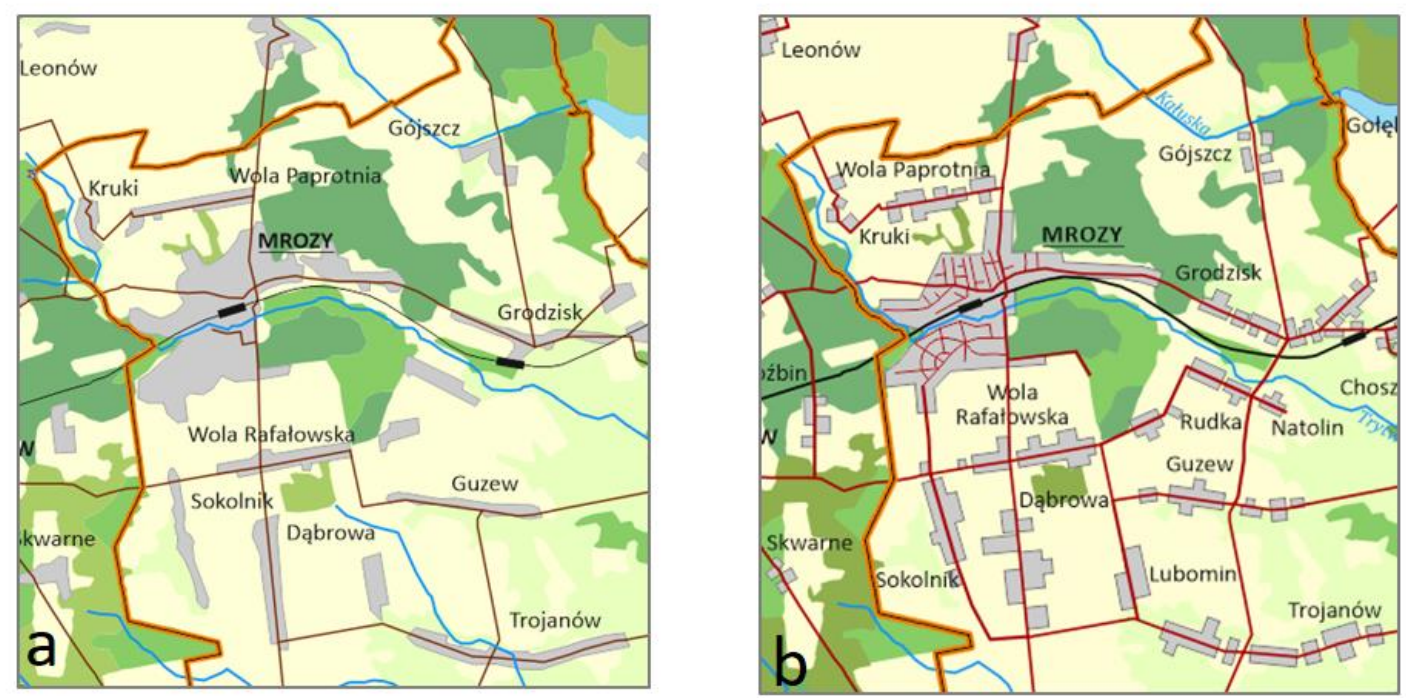

Figure 10. Buildings and roads: before modification (a) and after modification (b) (own elaboration)
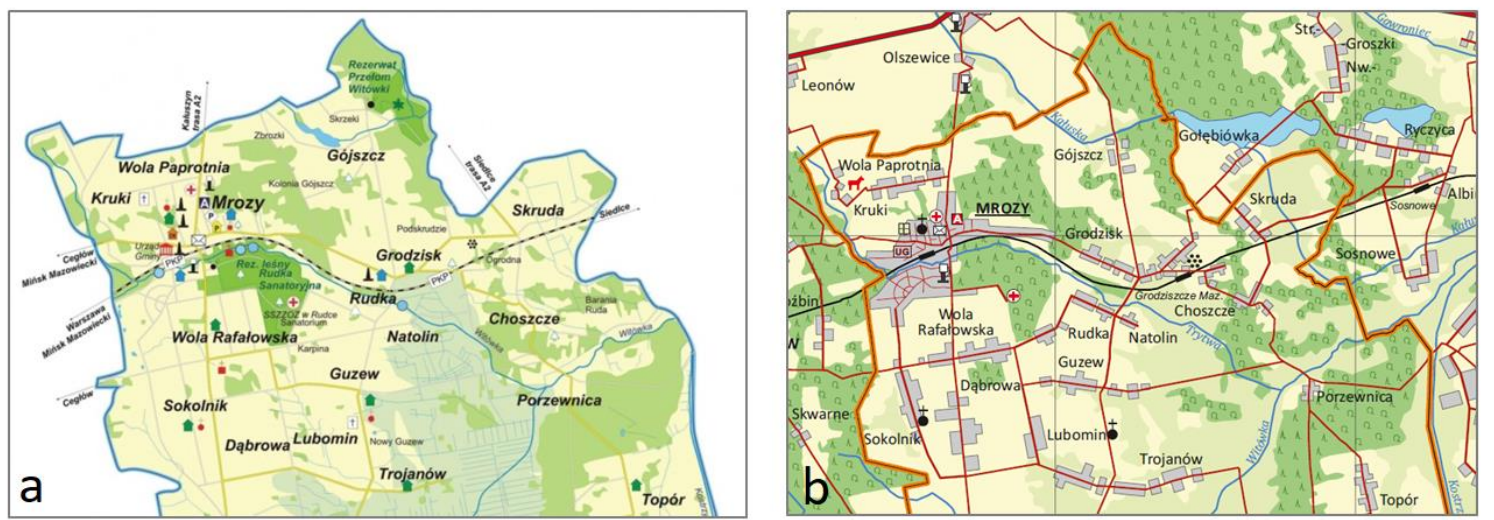

Figure 11. (a) Map of the Mrozy commune (fragm.) http://www.mrozy.pl/ (25th April 2017) (b) Map of the Mrozy commune (fragm.) (own elaboration)
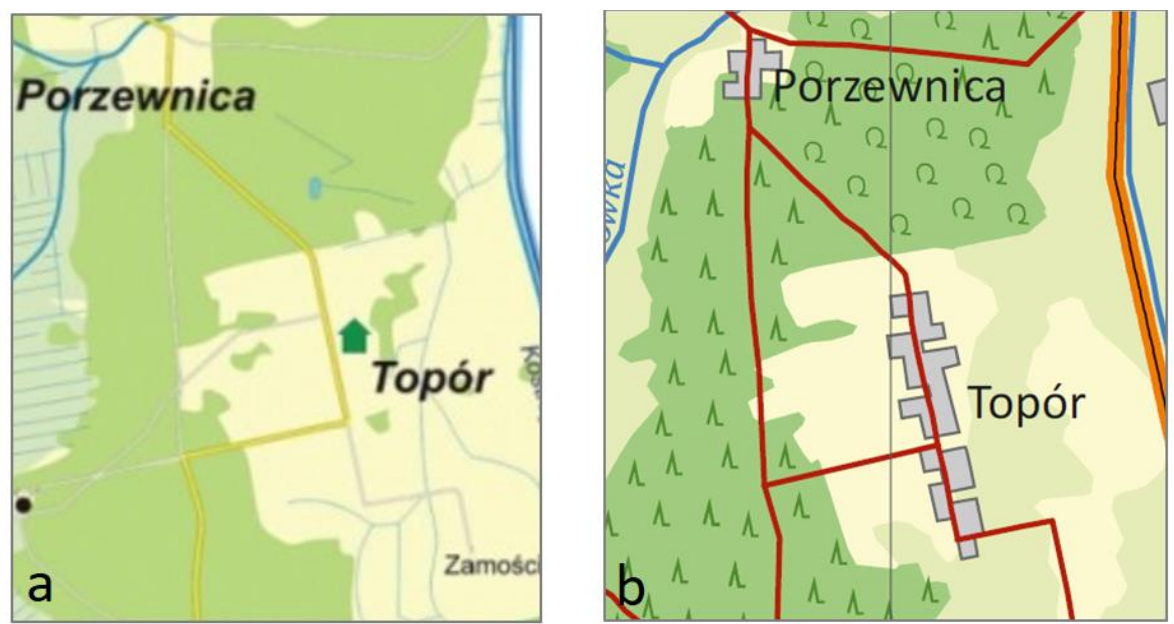

Figure 12. Different presentation of forest: a. Map of the Mrozy commune (fragm.) http://www.mrozy.pl/ (25th April 2017) b. Map of the Mrozy commune (fragm.) (own elaboration) 

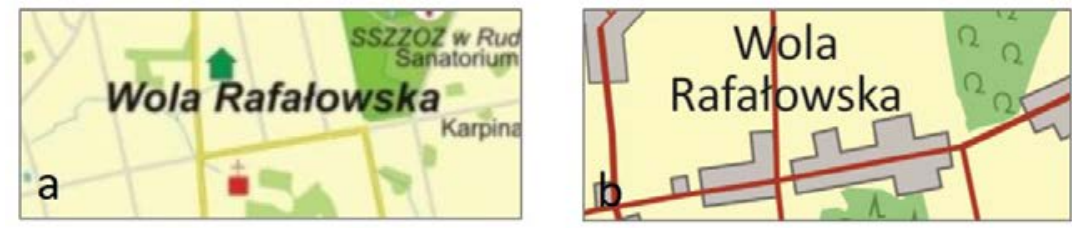

Figure 13. Differences in the presentation of the road network : a. Map of the Mrozy commune (fragm.) http://www.mrozy.pl//25th April 2017) b. Map of the Mrozy commune (fragm.) (own elaboration)

Reserves have been indicated (Figure 12a.). In our elaboration (Figure 12b.), the forest range is uniformly coloured, but a pattern is present in the middle symbolizing the dominant type of forest. There are no Nature Reserves presented on the map from the website.

One important aspect is the differences in the presentation of the road network (Figure 13.). The map available on the website of the Commune Office (Figure 13a.) contains a hierarchy of roads within the boundaries of the terrain, which is an undoubted advantage. There are two levels that distinguish between the main roads (probably county-wide roads), and others. There is no hierarchy of roads on the map of our own elaboration (Figure 13b.); only the primary roads outside the Mrozy commune have been marked.

\section{Conclusion}

The aim of this study was to produce a multivariable thematic presentation of a small region. The goal was achieved on the basis of the specific objectives of acquiring and visualizing the data and analysing the research area.
The result of the work is a series of thematic maps relating to the natural environment and to socio-economic issues. In summary, the above considerations lead to the conclusion that the results of the work carried out has significantly broadened the map resources of the community of Mrozy. We hope that the collected materials will allow other researchers to continue working on the topic. The developed maps present a general view of the phenomena occurring in the community; they may also serve as promotional materials and be used to publicize the wider community of Mrozy.

\section{Acknowledgements}

The data used in this research was acquired from the commune office of Mrozy, from the Centre for Geodesy and Cartography, and from the official website of the DirectorateGeneral for Environmental Protection (GDOS).

This research was supported by the Ministry of Science and Higher Education, Republic of Poland under the Theme no. 501-D119-64-180200-15.

\section{References}

Directory of areas Natura 2000. Available from: < http://obszary natura2000.org.pl/>. [7 July 2017].

Gołębiowska, I 2010, 'The role of map legend in the process of map use. Conclusions from an exploratory study', Miscellanea Geographica, vol. 14, pp. 341-348.

Gołębiowska, I 2015, 'Legend Layouts for Thematic Maps: a Case Study Integrating Usability Metrics with Think Aloud Method', Cartographic Journal, vol. 52, no 1, pp. 28-40.

Juśkiewicz, K (ed.) 2014, Mrozy. Wieś-miasto-gmina, Gminna Biblioteka Publiczna w Mrozach, Mrozy.

Kondracki, J 2013, Geografia regionalna Polski, Wydawnictwo Naukowe PWN, Warszawa.

Korycka-Skorupa, J 2002, 'Od danych do mapy', Polski Przegląd Kartograficzny, vol. 34, no 2, pp. 91-102.

Official website of Mrozy commune. Available from: < http://www. mrozy.pl/>. [25 August 2017].

Official website of the Directorate-General for Environmental Protection (GDOS). Available from: <https://www.gdos.gov. pl>. [25 May 2017].
Pasławski, J 2008, 'Z problematyki map kropkowych', Polski Przegląd Kartograficzny, vol. 40, no 4, pp. 349-361.

Ratajski, L 1989, Metodyka kartografii społeczno-gospodarczej, 2nd edn, PPWK, Warszawa.

Saliszczew, K 2002, Kartografia ogólna, Wydawnictwo Naukowe PWN, Warszawa.

Slocum, TA, McMaster, RB, Kessler, FC \& Howard, HH 2009, Thematic Cartography and Geovisualization, 3rd Edition, Pearson Prentice Hall, Upper Saddle River, NJ.

Spallek, W 2002, 'Metody prezentacji gęstości zjawisk rozproszonych na mapach tematycznych' Polski Przegląd Kartograficzny, vol.34, no 1, pp. 11-21.

Żyszkowska, W 2016, 'Visual features of cartographic representation in map perception', Polish Cartographical Review vol. 48, no. 1, pp. 5-15. 